\title{
The Identification of Surface Groups on the Surface-Treated Silica Gels through the Infrared Spectrat
}

\author{
Hiroshi UTSUG \\ Department of Applied Science, Faculty of Engineering, \\ Tohoku'University ; Sendai-shi, Japan
}

The infrared spectra $\left(4000 \sim 400 \mathrm{~cm}^{-1}\right)$ of silica gels, which were treated by alcohols with saturated linear or branched chain and with hexane solutions of normal alcohols $(C>5)$, aromatic alcohols, unsaturated alcohols and the dioles were investigated using the $\mathrm{KBr}$ disc technique. The absorption band at $950 \mathrm{~cm}^{-1}$ on the native silica gel was assigned to the bending vibration of the $\mathrm{Si}-\mathrm{OH}$ groups. No change of this band was observed on the treatment of the silica gel with hexane, whereas its intensity was decreased or disappeared on the treatment with alcohols. It may be concluded that the surface groups of the treated silica gels are not the physical adsorbed or chemisorbed alcohol, but the groups after reaction with the surface silanols. The infrared spectra of the surface-treated silica gels showed the absorption bands at the characteristic frequencies of the $\mathrm{CH}$ stretching or bending vibrations of the alkyl groups of the alcohols used. The infrared spectra of the silica gels treated by aromatic alcohols showed the absorption bands due to the $\mathrm{CH}$ deformation and $\mathrm{C}-\mathrm{C}$ skeltal bending vibrations. From these results, it was concluded that the surface groups on the treated silica gels were consisted of the alkyl groups of the alcohols.

$\dagger$ Studies on the Surface Treatment of the Ultrafine Powders. XVI.

（日本化学会誌，1972，p. 2244～2255）

\section{熱分析法による表面処理シリカゲル付着基の検討 ${ }^{122}$}

\author{
（1972 年 4 月 1 日受理）
}

\author{
宇津木弘・堀越 英生*
}

\begin{abstract}
末処理シリカダル，22 種類のフルコール（淔鎖，分枝䭒和フルコール，2 洒フルコール，芳香族フルコール，不 飽和アルコール)で処理したシリカゲルの付着基を, 空笑中 $20 \sim 800^{\circ} \mathrm{C}$ 間の示差熱, 熱重量分析で検討した結果, つ ぎの事柄が認められた。（1）示差熱分析は使用したフルコールの種類により特徽のある形を示す。（2）200 $\mathrm{C}$ 以下 の温度領域に水あるいは末反応フルコールの脱離による吸熱部分，これ以上の温度領城に付着基の熱分解酸化による

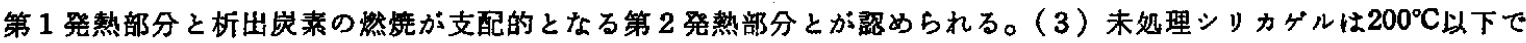
の吸熱部分と $200^{\circ} \mathrm{C}$ 以上でのシラノールの脱離と認めら机る高温での脱水部分が認められる。（4）付着基の分解酸

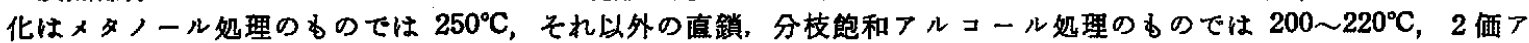
ルコール処理のるのでは $270 \sim 305^{\circ} \mathrm{C}$, 不飽和フルコール処理のすのでは $265 \sim 285^{\circ} \mathrm{C}$, 芳香族アルコール処理のすの

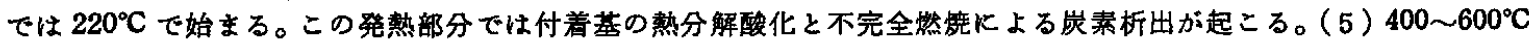
での発熱部分は析出炭案の然焼が支配的であり芳香族フルコール処理試料でいちじるしい。（6） $350,445,550^{\circ} \mathrm{C}$ まで加熱し急冷した 2 価アルコール処理した試料の赤外吸収スペクトルの検討から試料管の各部位でその組成が異な

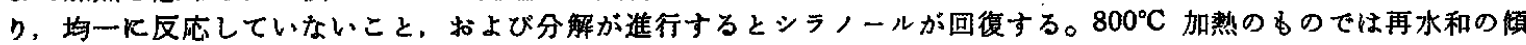
向なし。（７）tertーアルコール処理のシリカゲルは未処理シリカゲルと同じ示差熱・熱重需分析曲線を与える。また

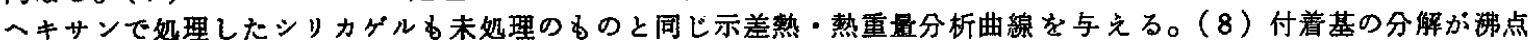
よりる高い温度で発熱反応として認められることから，付着基は昅着フルコールではなく，反応により化学結合して いると認められる。
\end{abstract}

\section{1 粕論}

金属酸化物はその生成の段階から表面は親水性であるが，その 表面水酸基に着目し，アルコールとエステル化反応させるなら ば, シリカゲルのみならずアルミナ，酸化亜鉛，磁性酸化物徽粉

1）この報文を“销粉体の表面処理に関する基碟的研究（第 17 報)”そする。

2）前報(第 16 報)，宇津木 弘，日化，1972，2237.
体についても粉体の基本的性質に大きな変化を与えることなく， 表面特性のみを親油性に変えらることが珰められだ。このよう な表面処理に関する検討には央用的な面からのみなされる場合が 多いので，その対象となる試薬はかきられている場合が多い。こ のよらな理由から表圌酸としての程度の強いシリカゲルにつき，

* 東北大学工学部店用理学教室, 仙台市荒巻字青葉

3）字津木 弘，渡辺昭輝，伊藤昆逸，西村成興，日化，91， 431(1970). 
ベンゼン環，二重結合なとの有機官能基をすつよらな広範囲にわ たるアルコールで処理し，親油性の度合性付着基の炭素鎖の長さ とすよるが, tert-アルコールあるい恃 2 価アルコール処理のるの 以外は，その構造のいかん仗かからず親油性表面任変わること が認められたか。この表面処理にさいしてシリカゲルと直接反応 しないーキサンのよらな溶媒を用いた溶液で反応させることは， とく滈沸点のアルコールの場合に有效であることが認めら れ゙，これらの点についてはさらに検討中である。このよらな表 面特性の变化を起こさせる付着基の同定に関しては，付着基は使 用したアルコールのアルキル基からなるとして炭素含量と表面䅡 とから単位表面積当たりの付着基数を求め，表面水酸基数との比 较から付着基は使用したアルロールのアルキル基であろらと推定 しだ) の)。より直接的な検討方法として,これら表面処理シリカゲ ルの赤外吸収スペクトルを検討し，付着基は使用したアルコール のアルキル基を含んでいることが確からられた2)。またこれら付 着基が吸着状熊で付着しているのか，表面シラノール基と反応し て結合しているかの判定はシリカゲルの表面シラノールによると 㸾められる $950 \mathrm{~cm}^{-1}$ の吸収に着目し，表面処理シリカゲルでは この吸取が減少または消失するところから，反応により付着して いると推定されだ。このような付着基の検討飞示差熱，熱重量 分析とをあわせて用いるならば付着基の分解温度とか減量とか ら、シリカゲル表面との結合の程度なとの付着基の性質の詳細も わかり，また付着基の同定る可能となるであろら。シリカゲル氏 ついての表面処理試料の示差筧，熱重量分析飞よる検討は種々試

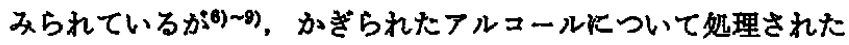
るのの場合が多い。そこで種々な有機官能基をるつ広範围炕わた るアルコールで表面処理された試料の元素分析化よる付着基数括

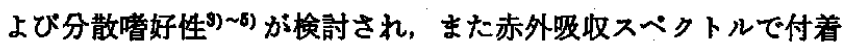
基が同定され2)，かつその表面特性の検討されたシリカゲルの示 差熱, 熱重量分析を行ない娭討し、三三の結果を得たので報告す る。

\section{2 実 験 方 法}

測定に使用したシリカゲルは市販クロマトグラフ用シリカゲル SK 2, SK 3 を表面処理したるのである。表面处理は常温で夜体 であるような低沸点アルコールではアルコールのみ，高沸点アル コールではーキサンの臨界点付近の高温, 高压下で 30 分程度反 応させ，排気させることによりなされだ)す。た 2 価アルコー ルはへキサンには溶けないので, シリカゲルをアルコールに漫漬 し，これkへキサンを加え，オートクレーブを用いへキサン雾囲 気中で反応させだ)。へキサン溶液を用いた愓合にはアルコール， アセトン、ベンゼン、へキサンなどで十分洗浄し，末反応アルコ 一ルを除去した。処理に用いたアルコールは直鎖飽和アルコール であるタタノール，エタノール，プタノール，ペンタノール， -

4) 宇津木 弘，西村成興，加野哲郎，日化，1972，1550；材 料, 21，528(1972).

5）宇津木 弘, 酉村成興, 日化, 92, 759(1971)；材料，20, 737 (1971).

6) 北原䨌登，浅野利行，広瀬 務，日化，92，377(1971).

7) K. R. Lange, Chem.Ind., 1968, 441 ; 1969, 1273.

8）赤林 宏, 吉田明利，大坪義雄，工化，68，429(1965); $69,1882(1966) ; 70,156(1967)$.

9) J. J. Fripiat, Helv. Chim. Acta, 43, 176(1960).
キサノール，オクタノール，デカノール，ドデカノール，テトラ デカノール（これらで处理した裁料忹 HMSK 2, HMSK 3, HESK 2, n-HBSK 2, HASK 2, HHSK 2, OSK 31, DSK 31, DDSK 31，MySK 31 と呼占）と分枝飽和アルコールであるisoブタノール, sec-ブタノール, tert-ブタノール, tert-ペンタノー $\sim$ (iso-HBSK 2, sec-HBSK 2, tert-HBSK 2 , tert-HBSK 3 , tert-HASK 2) と2 価アルコールとして 1,4-，1，3-特よひ2,3ブタンジオール，1,2-プロ パンジオール (1, 4-BGSK 31, 1,3BGSK 31，2,3-BGSK 31，1,2-PrGSK 31) とベンゼン罢なとの 官能基をすつ芳香族アルコールであるベンジルアルコール，1-フ エニルエタノール, 2-フェニルエタノール, 3-フェニルプロパ ール (BZSK 31, 1-PhESK 31, 2-PhESK 31, 3-PhPrSK 31), および二重結合をるつアルコールとしてのアリルアルコール

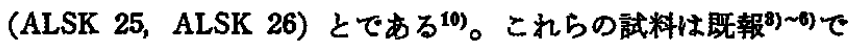
使用された試料と同一試料である。また未処理シリカゲル SK 2, SK 3 拈よびこれをへキサンで処理した SK 2 ( $n$-hexane), SK 3 (n-hexane) および活性炭11) 3.38\% 混入したシリカゲル SK 3 (AC, 3.38\%) る比較のため湘定試料とした。示差熱，熱重量分

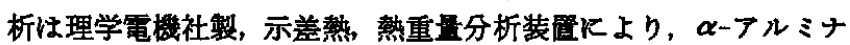
を基準物質とし，昇温速度 $5^{\circ} \mathrm{C} / \mathrm{min} て ゙ ~ 20 \sim 800^{\circ} \mathrm{C}$ 飞わたり空気 中で測定された 12 )。試料採取量は $0.3 \sim 0.45 \mathrm{~g}$ である。分解過程 の険討飞用いた赤外吸收スベクトルの揤定は $\mathrm{KBr}$ 錠剂法で Perkin Elmer 337 型分光器飞より行なわれた

\section{3 実 結 果}

未処理シリカゲル，表面処理シリカゲルの表面处理条件，表面 積および表面処理アルコールの沸点あるい性融点を表 1 亿示す。 これら試料の元素分析，表面積および付着基数は表 2 に示した。 末処理シリカゲル、へキサン処理シリカゲルと活性炭灄入シリカ ゲル括よび表面処理シリカゲルの示差熱, 熱重量分析の結果は国 1 亿示した。つぎに一定速度で昇温加熱した試料 1,4-BGSK 31 を特定温度で急冷し，試料管での上部，底部試料の赤外吸収 ペクトルを測定した。急冷するまでの示差熱，熱重量分析曲線江 図2に示したが，それぞれの傾向（1A，2A，3A，4A）は測定 された温度範国内で完全に一致する。350，445，550，800 で加熱し，急冷後試料管の上部と底部他ある試料の赤外吸収スペ クトルは四3K示した。 $800^{\circ} \mathrm{C}$ 処理陚料では上部，底部とすに同 じ赤外吸収スペクトルを示すので，上部のもの纪ついて示した。 これらの試料の色は $350^{\circ} \mathrm{C}$ 加熱試料では上部が淡黄裼色，底部は 白色である。 $445^{\circ} \mathrm{C}$ 加熱の試料では上部は浱茶褐色，底部は白色 であるが，550 加熱試料ではこれに反し上部は白色，底部は濃 茶褐色である。また $800^{\circ} \mathrm{C}$ 処理試料では上部, 底部とるに白色で ある。图1に示した示差熱曲線で現われる吸熱, 発熱ピークの温 度と, この曲線の傾向を考慮して熱重量分析曲線とから求められ る吸熱减量, 発等減量とそれぞれの温度範囲恃表 3 亿示した。 ぎにこれら試料の赤外吸収スペクトル図 3 の $950,800 \mathrm{~cm}^{-1}$ 吸収

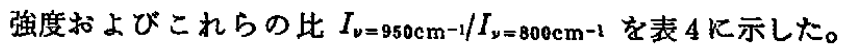

10）表面処理試料の記号は既報出)飞示した方法にしたがった.

11）宇津木 弘，小林昭夫，藤田武敏，日化，89，1177(1968).

12）示差熱, 熱重量分析の測定恃東北大学工学部田中弘文教授 の御好意化よる.

13）赤外吸取スペクトルの测定は東北大学工学部会田高淂数授 の御好意比よる。 


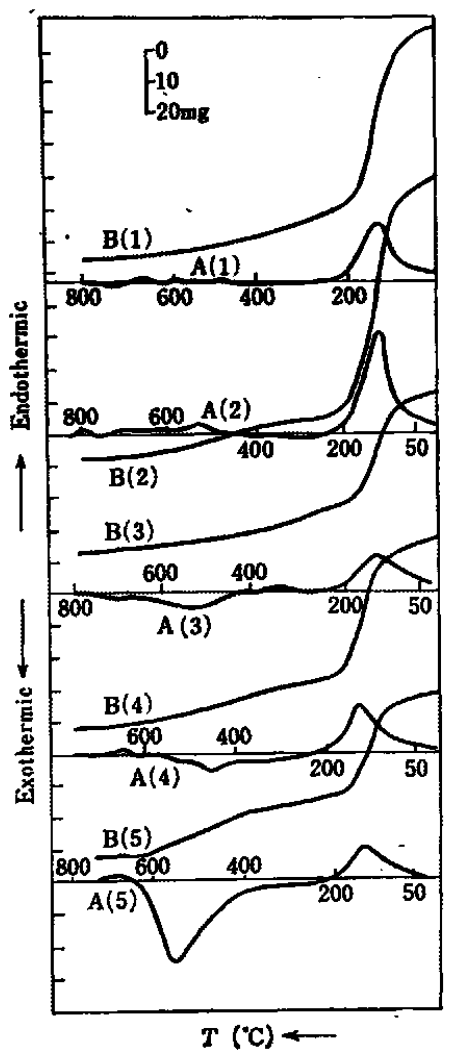

Fig. 1 (I)

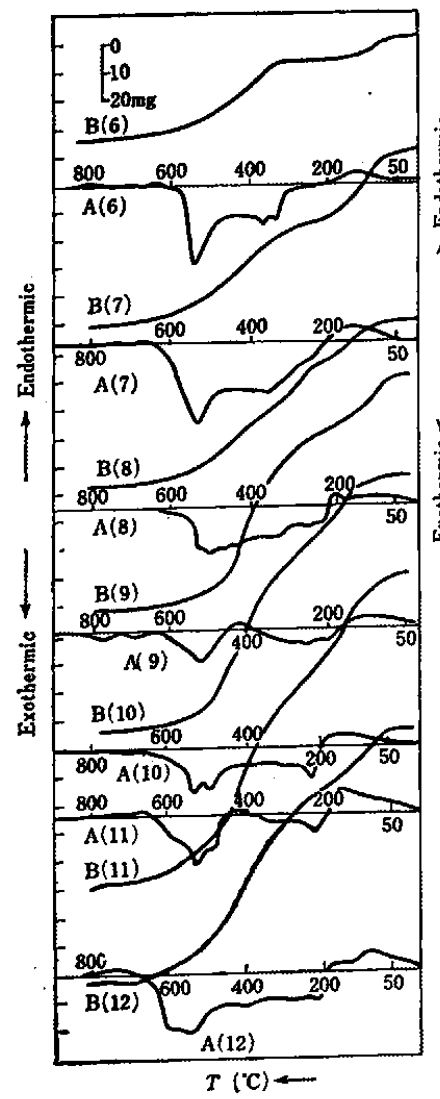

Fig. 1 (II)

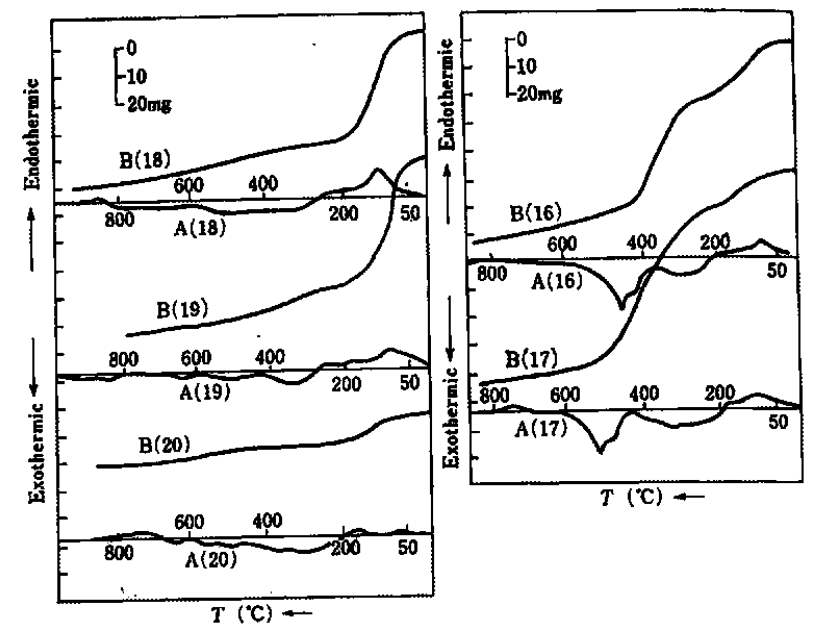

Fig. 1 （III)

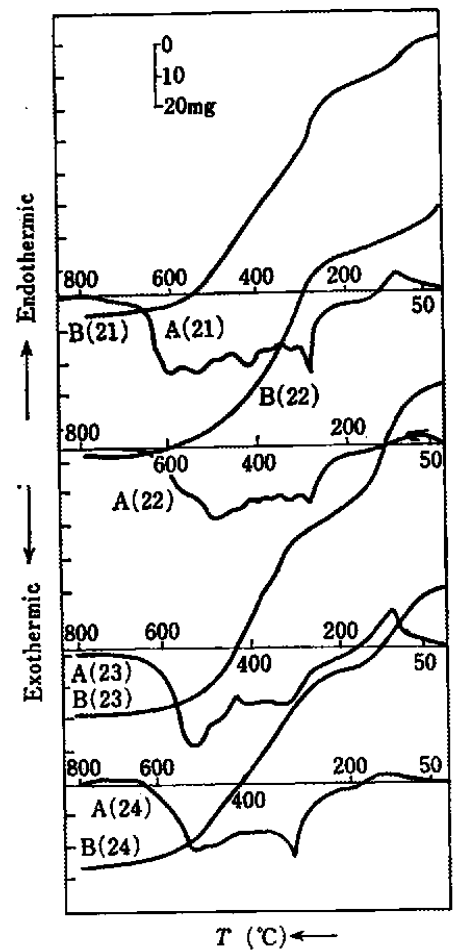

Fig. 1 (N)
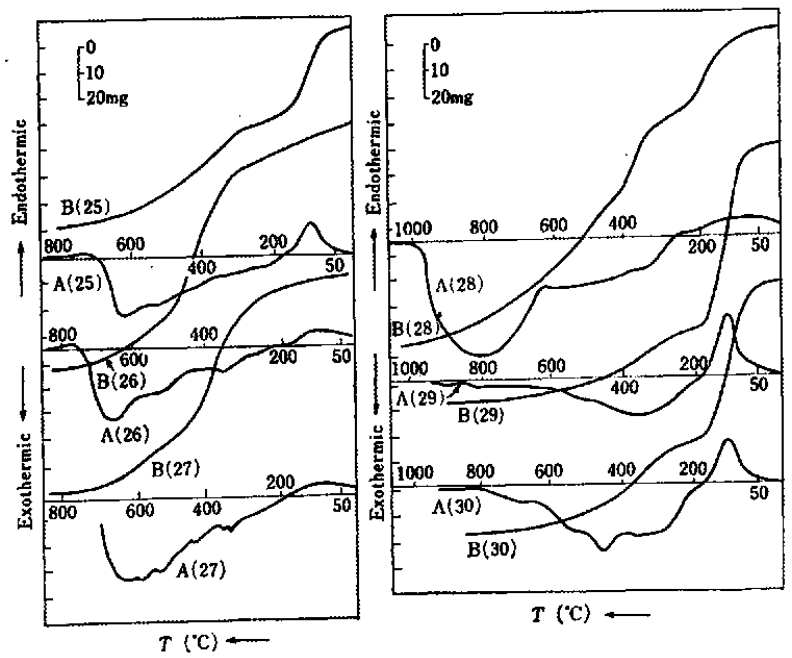

Fig. 1 (V) 
Fig. 1 The differential thermal and thermogravimetric analysis of the native and the surface-treated silica gels A : DTA curve, B : TGA curve

The number in the parenthesis is the curve No.

(I) : The native silica gels, silica gels treated by $n$-hexane and silica gel mixed with activated carbon.

(1) : SK $2(0.3824 \mathrm{~g})$, ( 2) : SK 2 (n-hexane) $(0.4502 \mathrm{~g})$, ( 3 ): SK $3(0.3269 \mathrm{~g})$, ( 4$):$ SK 3 (n-hexane) (0.3982 g),

(5) : SK 3 (AC 3. 38\%). (0.2726 g)

(II) : The silica gels treated by alcohol with the linear saturated carbon chain.

(6) : HMSK $3(0.3512 \mathrm{~g})$, ( 7 ) : HMSK $2(0.3830 \mathrm{~g}),(8)$ : HESK $2(0.4055 \mathrm{~g}),(9): n$-HBSK $2(0.4158 \mathrm{~g})$, (10); HASK $2(0.4412 \mathrm{~g}),(11)$ : HHSK $2(0.4398 \mathrm{~g}),(12)$ : OSK $31(0.3915 \mathrm{~g}),(13)$ : DSK $31(0.4160 \mathrm{~g})$, (14): DDSK 21 $(0.4632 \mathrm{~g})$, (15) : MySK $31(0.4135 \mathrm{~g})$

(II) : The silica gels treated by alcohol with the saturated and branched carbon chain.

(16) : sec-HBSK $2(0.4198 \mathrm{~g}), \quad(17):$ iso-HBSK $2(0.4271 \mathrm{~g}), \quad(18):$ tert-HBSK $2(0.4145 \mathrm{~g})$, (19): tert-HBSK 3 $(0.4186 \mathrm{~g}),(20):$ tert-HASK $3(0.3436 \mathrm{~g})$

(N): The silica gels treated by diole.

(21) : 1, 4-BGSK $31(0.3895 \mathrm{~g})$, (22) : 2, 3-BGSK $31(0.3540 \mathrm{~g}),(23): 1,3-$ BGSK $31(0.4132 \mathrm{~g}),(24): 1,2-P r G S K ~ 31$ $(0.3945 \mathrm{~g})$

(v) : The silica gels treated by the aromatic alcohol and by the unsaturated alcohol.

(25) : 1-PhESK $31(0.3730 \mathrm{~g})$, (26) : 2-PhESK $31(0.3851 \mathrm{~g})$, (27) : 3-PhPrSK $31(0.3376 \mathrm{~g})$, (28) : BZSK 31 (0. 4021 g), (29) : ALSK $25(0.4454 \mathrm{~g})$, (30): ALSK $26(0.4138 \mathrm{~g})$

Table 1 The conditions of the surface-treatment and surface areas of the native or the surface-treated silica gels and the normal boiling point of the alcohols

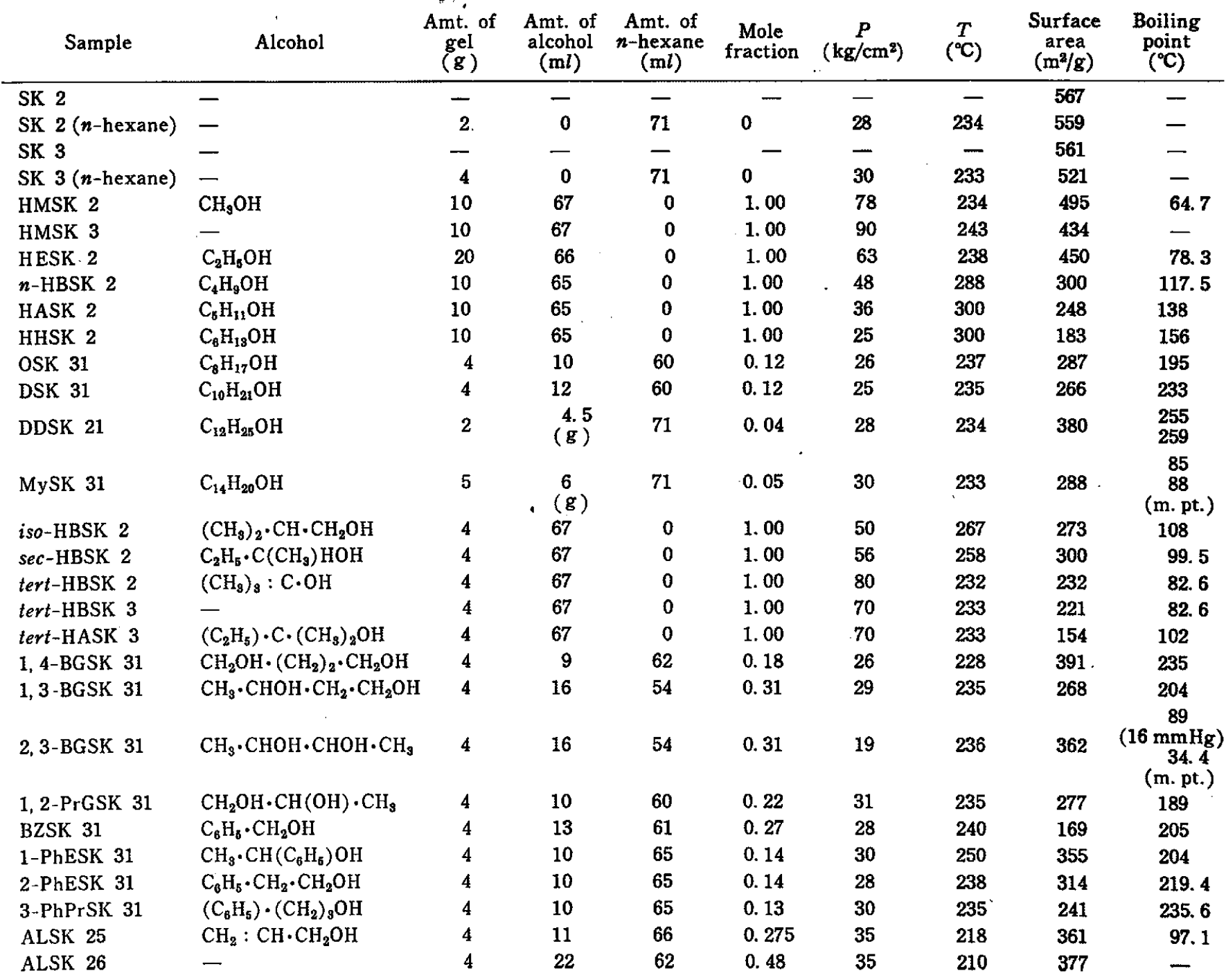


Table 2 The contents of carbon and hydrogen and the numbers of the surface group of the native of surface-treated silica gels

\begin{tabular}{|c|c|c|c|c|c|c|c|}
\hline \multirow[b]{2}{*}{ Sample } & \multirow[b]{2}{*}{ Alcohol } & \multicolumn{3}{|c|}{ Elemental analysis } & \multicolumn{3}{|c|}{$\begin{array}{c}\text { Thermogravimetric } \\
\text { analysis }\end{array}$} \\
\hline & & $\stackrel{c}{\%}$ & $\underset{(\%)}{\mathbf{H}}$ & $\begin{array}{l}\text { Numbers of } \\
\text { surface group } \\
\left(\mathrm{cm}^{-1}\right) \times 10^{-14}\end{array}$ & $\overparen{C}$ & $\underset{(\%)}{\mathrm{H}}$ & $\stackrel{\mathrm{c}}{(\%)}$ \\
\hline SK 2 & - & 0.08 & 2.31 & - & - & 2.10 & - \\
\hline SK 2 (n-hexane) & 一 & 0.85 & 2.27 & 0.11 & - & 2. 12 & - \\
\hline SK 3 & - & 0.07 & 2.07 & - & - & 1.64 & 一 \\
\hline SK 3 (n-hexane) & 一 & 1.79 & 2. 27 & 0.29 & - & 1.66 & - \\
\hline SK 3 (AC 3. 38\%) & - & - & - & - & 2. 56 & 1.61 & - \\
\hline HMSK 2 & $\mathrm{CH}_{3} \mathrm{OH}$ & 5.42 & 1.97 & 5.50 & 5.00 & 1.16 & 7.94 \\
\hline HMSK 3 & - & 3.74 & 1. 42 & 4. 32 & 3.69 & 0.66 & 6. 61 \\
\hline HESK 2 & $\mathrm{C}_{2} \mathrm{H}_{5} \mathrm{OH}$ & 5.59 & 1.43 & 3.12 & 5.06 & 0.81 & 8. 08 \\
\hline n-HBSK 2 & $\mathrm{C}_{4} \mathrm{H}_{9} \mathrm{OH}$ & 11.92 & 2.77 & 4.99 & 9.09 & 1.18 & 12.95 \\
\hline HASK 2 & $\mathrm{C}_{5} \mathrm{H}_{11} \mathrm{OH}$ & 13. 55 & 2.99 & 5. 48 & 10.18 & 0.93 & 13. 41 \\
\hline HHSK 2 & $\mathrm{C}_{6} \mathrm{H}_{18} \mathrm{OH}$ & 13. 31 & 2.81 & 6.08 & 11.19 & 1.16 & 13. 67 \\
\hline OSK 31 & $\mathrm{C}_{8} \mathrm{H}_{17} \mathrm{OH}$ & 10.78 & 2.55 & 2.08 & 11.33 & 1.07 & 14.76 \\
\hline DSK 31 & $\mathrm{C}_{10} \mathrm{H}_{21} \mathrm{OH}$ & 13. 53 & 3. 08 & 2. 35 & 12.11 & 1.09 & 15. 55 \\
\hline DDSK 21 & $\mathrm{C}_{12} \mathrm{H}_{25} \mathrm{OH}$ & 14: 61 & 3.60 & 1. 61 & 13. 49 & 1.55 & 16. 34 \\
\hline MySK 31 & $\mathrm{C}_{14} \mathrm{H}_{28} \mathrm{OH}$ & 15. 07 & 3. 59 & 1.90 & 14. 08 & 0.93 & 17.53 \\
\hline iso-HBSK 2 & $\left(\mathrm{CH}_{8}\right)_{2} \cdot \mathrm{CH} \cdot \mathrm{CH}_{2} \mathrm{OH}$ & 10.92 & 2. 49 & 5.00 & 9.40 & 0.76 & 12.45 \\
\hline sec-HBSK 2 & $\left(\mathrm{C}_{2} \mathrm{H}_{5}\right) \cdot \mathrm{CH}\left(\mathrm{CH}_{3}\right) \mathrm{OH}$ & 8.63 & 2.09 & 3. 60 & 6.98 & 1.04 & 10.03 \\
\hline tert-HBSK 2 & $\left(\mathrm{CH}_{\mathrm{s}}\right)_{\mathbf{s}} \cdot \mathrm{C}(\mathrm{OH})$ & 1.57 & 1.79 & 0.85 & 0 & 1.47 & - \\
\hline tert-HBSK 3 & $\therefore$ & 1.91 & 1.29 & 1.08 & 0 & 1.52 & - \\
\hline tert-HASK 3 & $\left(\mathrm{C}_{2} \mathrm{H}_{6}\right) \cdot \mathrm{C}\left(\mathrm{CH}_{3}\right)_{2} \mathrm{OH}$ & 1.35 & 0.94 & 0.86 & 0 & 0.71 & - \\
\hline 1, 4-BGSK 31 & $\mathrm{CH}_{2} \mathrm{OH} \cdot\left(\mathrm{CH}_{2}\right)_{2} \cdot \mathrm{CH}_{2} \mathrm{OH}$ & 10.18 & 2.36 & 3. 27 & 9.22 & 0.87 & 12.14 \\
\hline 1, 3-BGSK 31 & $\mathrm{CH}_{8} \cdot \mathrm{CHOH} \cdot \mathrm{CH}_{2} \cdot \mathrm{CH}_{2} \mathrm{OH}$ & 9.93 & 2.82 & 4. 27 & 6.73 & 1.58 & 9. 39 \\
\hline 2,3-BGSK 31 & $\mathrm{CH}_{\mathrm{g}} \cdot \mathrm{CHOH} \cdot \mathrm{CHOH} \cdot \mathrm{CH}_{3}$ & 10.89 & 2.38 & 3.76 & 8.11 & 1.07 & 10.77 \\
\hline 1,2-PrGSK 31 & $\mathrm{CH}_{2} \mathrm{OH} \cdot \mathrm{CHOH} \cdot \mathrm{CH}_{3}$ & 9.28 & 1.98 & 5. 60 & 6.74 & 1.12 & 9.45 \\
\hline BZSK 31 & $\mathrm{C}_{6} \mathrm{H}_{6} \cdot \mathrm{CH}_{2} \mathrm{OH}$ & 17.68 & 2.11 & 8. 50 & 15. 36 & 1.39 & 19.04 \\
\hline 1-PhESK 31 & $\mathrm{CH}_{8} \cdot \mathrm{CH}\left(\mathrm{C}_{6} \mathrm{H}_{6}\right) \mathrm{OH}$ & 6.51 & 1.68 & 1.16 & 5.33 & 1.58 & 8.98 \\
\hline 2-PhESK 31 & $\mathrm{C}_{6} \mathrm{H}_{6} \cdot \mathrm{CH}_{2} \cdot \mathrm{CH}_{2} \mathrm{OH}$ & 15.55 & 2.13 & 3. 10 & 14.91 & 0.85 & 18. 57 \\
\hline 3-PhPrSK 31 & $\mathrm{C}_{6} \mathrm{H}_{6} \cdot\left(\mathrm{CH}_{2}\right)_{3} \mathrm{OH}$ & 17.64 & 2. 37 & 4. 07 & 16.62 & 0.62 & 20.26 \\
\hline ALSK 25 & $\mathrm{CH}_{2}: \mathrm{CH} \cdot \mathrm{CH}_{2} \mathrm{OH}$ & 8. 40 & 1.88 & 3.90 & 2.15 & 2. 22 & 5.32 \\
\hline ALSK 26 & - & 9.59 & 2. 00 & 4. 26 & 3.62 & 2.08 & 6.76 \\
\hline
\end{tabular}

$950 \mathrm{~cm}^{-1}$ の吸收は采統的炕表面処理されたシリカゲルについて の検討から、 $\rightarrow \mathrm{SiOH}$ の変角振動によると带属されることが前 報2)に示された。

末処理シリカゲル括よび nーヘキサン処理シリカゲルの熱重量 分析曲線での全重量減を，脱離種は水であるとして求められた水 素含量は表 2 第 7 列㐳示した。表面処理試料の示差熱分析曲線を 参考とし，熱重量分析曲線から求められた発熱減量からSK 2 ま たはSK 3 の重量减少がゆるやかになる $200^{\circ} \mathrm{C}$ 以上 $800^{\circ} \mathrm{C}$ までに 示される高温部での減量を差し引き，付着基が使用したアルニー ルのアルキル基として求められた炭素含量を表 2 第 6 列飞, 吸熱 減量に SK 2 またはSK 3 の高温部での減量を加えて求められ る水素含量を表 2 第 7 列に示した。また発熱減量がすべてアルキ ル基によるとして求められた炭素含量は表 2 第 8 列飞併示した。 tertーアルコールで処理した試料の示差熱分析を参考として, 全減 少重量は水によるとして求められた水素含量は表 2 第 7 列に示し た。

\section{4 結 果 の 検 討}

\section{1 示差熱分析曲線}

一定の昇温速度で測定された表面処理試料の示差熱分析曲線は 付着基あるいは表面処理に用いたアルコール，たとえば直鎖，分
枝，2 洒，芳香族，不飽和アルコールといった種類により，それ ぞれ特㣲のある形を示し，この形は同種アルコールでは炭素鎖の 長さには関係しない。これらの形は末処理シリカゲル，あるいは 表面特性, 赤外吸収スペクトルなど検討では付着基の認められ ないーキサン処理シリカゲルによるるのなどとはいちしるしく異 なる。したがってこれらの形は付着基の種類により特徽つ゚けられ ていると考えらるであるら。一般に飽和炭化㟗素の酸化は少なく ともとの初期段階では骨格の C-C 結合は影響されす，C-H 結合

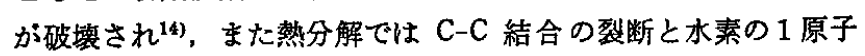
の転位が起こる15)。前者は発熱, 後者は吸熱である。図 1 に示さ れるよ5に椥重量曲線の第 2 減量部分で示羔熱分析曲線は発熱を 示すのであるから，空気中で行なわれる示差熱分析ではこれらの 反応が同時他起きると考兄られる。これらの酸化または分解反応 の起こる割合は試料管内部への酸素の拡散により支配されるであ ろら。これらの観点から使用した処理アルコールの種類ごとに示 盖熱曲線の詳細炕つき検討する。

4.1.1 未姏理, へキサン処理および活性炭混入シリカゲル: 未処理シリカゲル SK 2 拉よび SK 3 の示差熱分析曲線は $120^{\circ} \mathrm{C}$ または $130^{\circ} \mathrm{C}$ に吸熱ピークをもつ $200^{\circ} \mathrm{C}$ 以下での吸第部分とわ

14）小田霓三, “分解酸化”, 石油化学会糄, 朝倉 (1962)p. 137. 15）原 伸宜, 文献 14) の p. 5 . 


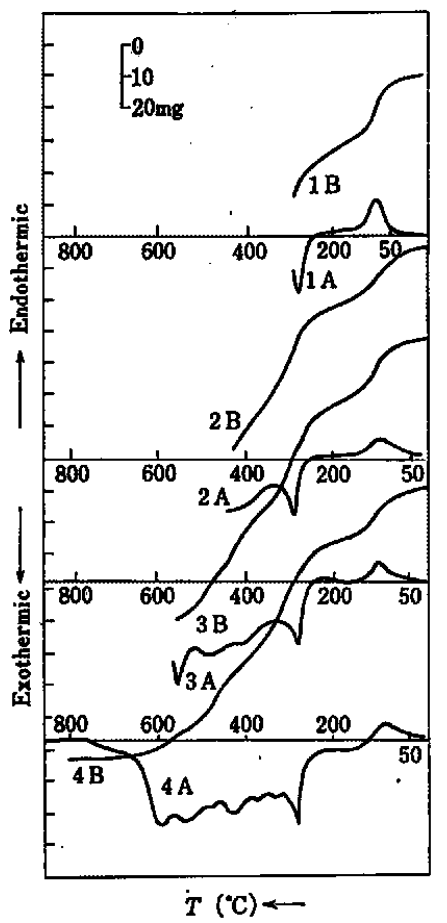

Fig. 2 The DTA and TGA curves of 1, 4-BGSK 31 before quenching at certain temperatures

A : DTA curve, B : TGA curve $t$.

The quenching temperatures $\left({ }^{\circ} \mathrm{C}\right)-$

$1: 350,2: 445,3: 550,4: 800$
Fig. 3 The IR absorption spectra of 1,4-BGSK 31 in the top or bottom region of the sample tube after quenching at certain temperatures

(1) : 1, 4-BGSK 31 (white)

(2): The sample in the upper region of sample tube after quenching at $350^{\circ} \mathrm{C}$ (pale brownish yellow)

(3): The sample in the bottom region of sample tube after quenching at $350^{\circ} \mathrm{C}$ (white)

(4) : The sample in the upper region of sample tube after quenching at $445^{\circ} \mathrm{C}$ (brown)

(5): The sample in the bottom region of sample tube after quenching at $445^{\circ} \mathrm{C}$ (white)

(6) : The sample in the upper region of sample tube after quenching at $550^{\circ} \mathrm{C}$ (white)

(7) : The sample in the bottom region of sample tube after quenching at $550^{\circ} \mathrm{C}$ (brown)

(8): The sample after quenching at $800^{\circ} \mathrm{C}$ (white)

(9) : SK 3

(10) : SK 3 (n-hexane)

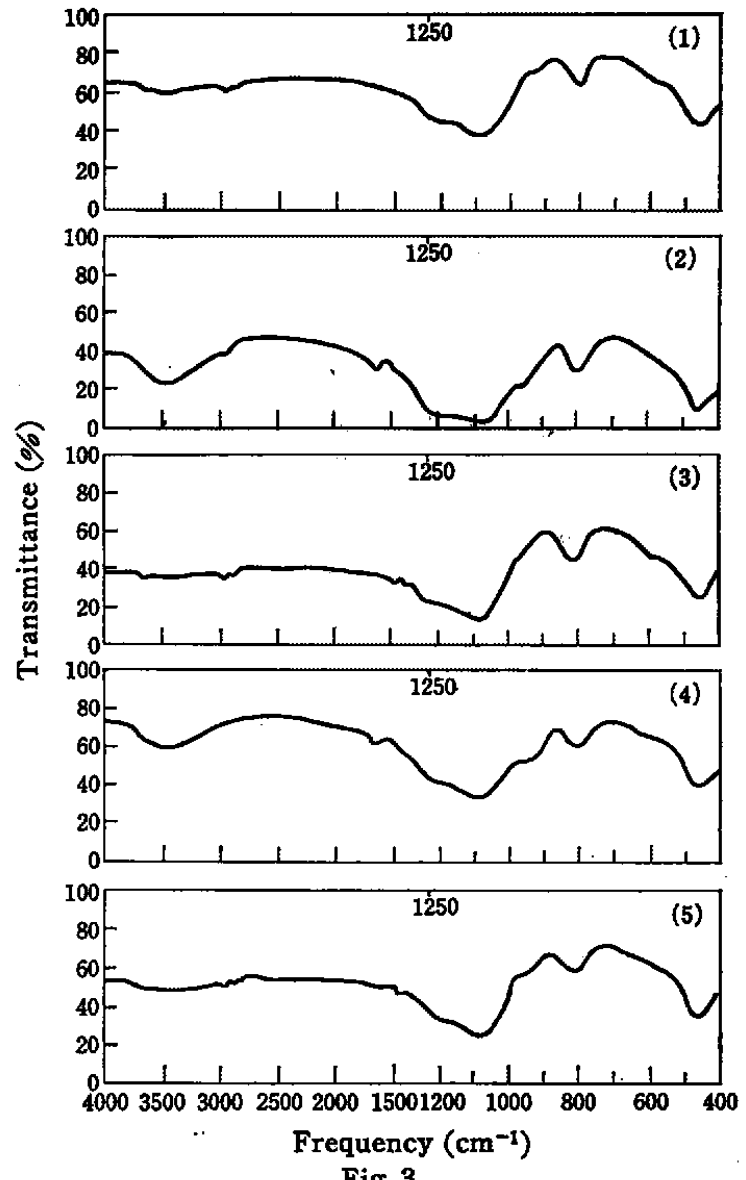

Fig. 3
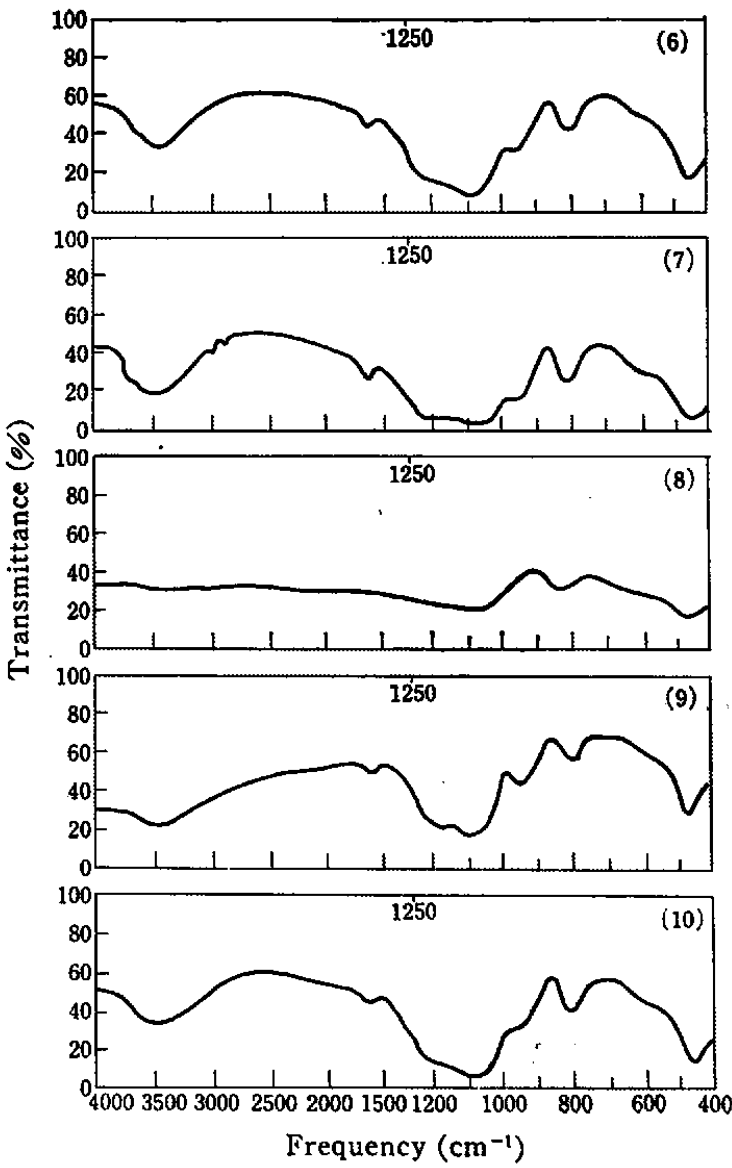

Fig. 3 
Table 3 The amounts of endothermic decrease and of the exothermic decrease in the thermogravimetric analysis of the native and the surface-treated silica gels and their respective temperature region

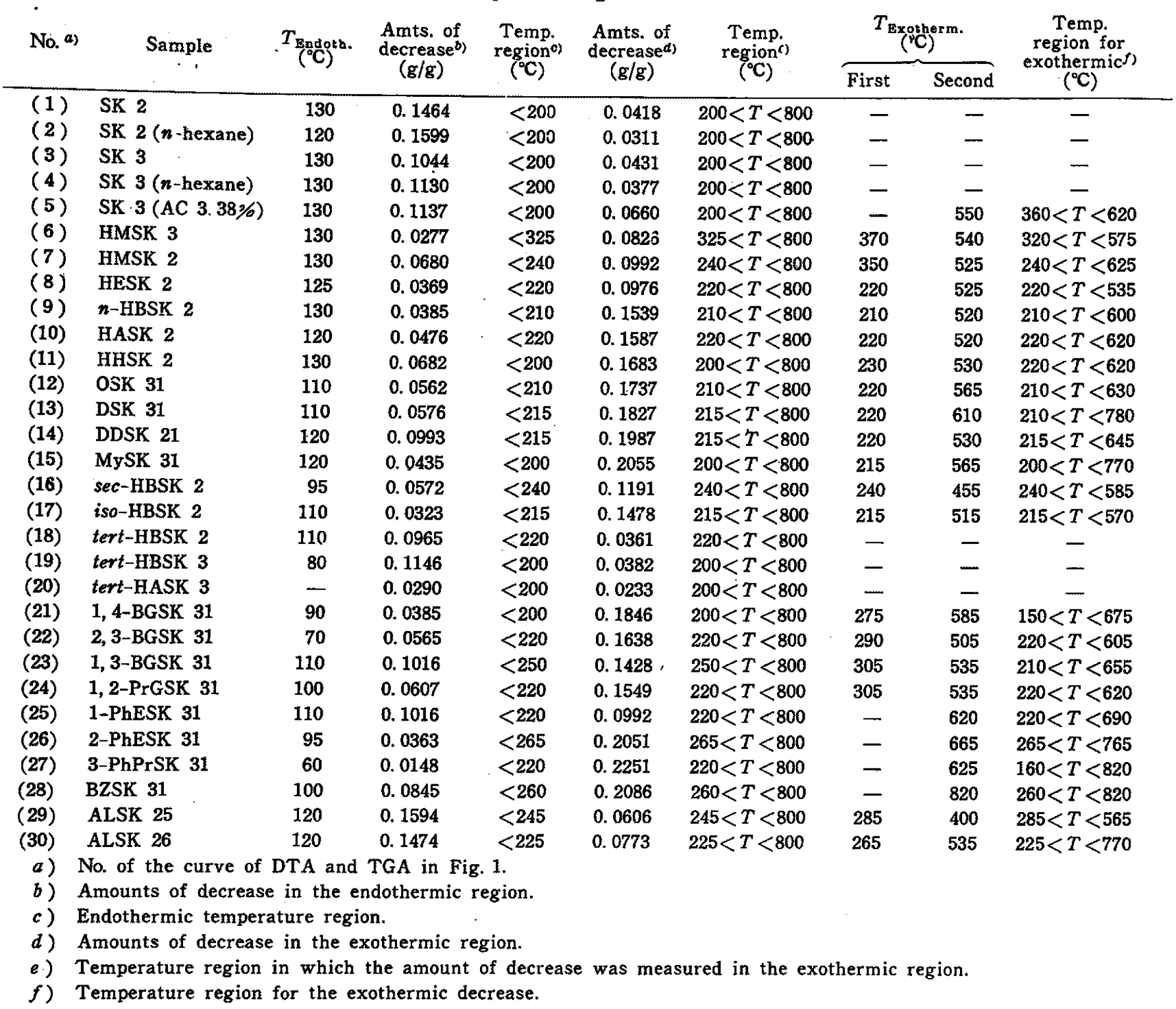

Table 4 The strength of the absorption of IR spectra at $950 \mathrm{~cm}^{-1}$ and at $800 \mathrm{~cm}^{-1}$ and their ratios of the 1,4-BGSK 31 in the upper or bottom region of the sample tube after quenching at a certain temperature

The posi-

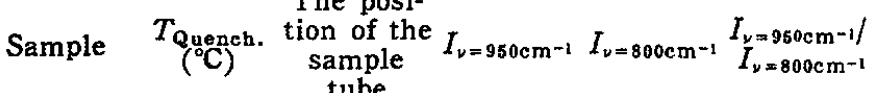
tube

\begin{tabular}{|c|c|c|c|c|c|}
\hline SK 3 & - & - & 25 & 14 & 1.78 \\
\hline $\begin{array}{l}\text { SK } 3 \\
\text { ( } n \text {-hexane) }\end{array}$ & - & - & 28 & 18 & 1. 56 \\
\hline \multirow{5}{*}{$\begin{array}{l}1,4- \\
\text { BGSK } 31\end{array}$} & - & - & 10 & 15 & 0.67 \\
\hline & 350 & $\begin{array}{l}\text { upper } \\
\text { bottom }\end{array}$ & $\begin{array}{l}25 \\
11\end{array}$ & $\begin{array}{l}18 \\
17\end{array}$ & $\begin{array}{l}1.39 \\
0.65\end{array}$ \\
\hline & 445 & $\begin{array}{l}\text { upper } \\
\text { bottom }\end{array}$ & $\begin{array}{l}20 \\
11\end{array}$ & $\begin{array}{l}11 \\
15\end{array}$ & $\begin{array}{l}1.82 \\
0.73\end{array}$ \\
\hline & 550 & $\begin{array}{l}\text { upper } \\
\text { bottom }\end{array}$ & $\begin{array}{l}29 \\
28\end{array}$ & $\begin{array}{l}18 \\
19\end{array}$ & $\begin{array}{l}1.65 \\
1.47\end{array}$ \\
\hline & 800 & - & 0 & 10 & 0 \\
\hline
\end{tabular}

ずかな発熱むしくは示差熱分析曲線では明瞭でない熱の出入りの 小さな $200^{\circ} \mathrm{C}$ 以上の高温部分で, 熱重量分析曲線では明らかな重 量減少を示す $200 \sim 800^{\circ} \mathrm{C}$ 部分とにわけられる（表 3，図 1（I）の 曲線（1）と（3))。これらをへキサンで処理した試料の場合に はこれと同じ㖽向が認められる（表 3，図 1 (I) の曲線（2）之 (4))。これはシリカゲルがへキサンとは反応しないことを示す と考えられ，前報2)文の結論の一部を支持するものである。活性 炭を混入したシリカゲル SK 3 (AC 3.38\%) の示差熱分析曲線 は図 1 (I) の曲線 ( 5 ) K示されるよ に発熱ピークを示す。同図の曲線（1），（2），（3）および（4） との比較から，この部分は活性炭の然㸁による発熱部分と考えら れる。したがって炭素は $400^{\circ} \mathrm{C}$ 付近で然焼し始め, 混入量にも上 るが $600^{\circ} \mathrm{C}$ 付近で然䇠しつくすと考えらるであろら。この温庋 $\left(400^{\circ} \mathrm{C}\right.$ 付近) は通常用いられる活性炭の賦活温度であり, 酸化 然爙温度でもある ${ }^{16)}$ 。

4.1 .2 直鎖飽和アルコール処理シリカゲル：直鎖飽和アルコ 
ールで処理したシリカダルではメタノール処理以外のものでは炭 秦鎖の長さにかかわらず, $110 \sim 130^{\circ} \mathrm{C}$ 吸收ピークをもつ 200 $220^{\circ} \mathrm{C}$ 以下での吸熱部分と $200 \sim 230^{\circ} \mathrm{C}$ 火急游な発熱（第 1 発熱

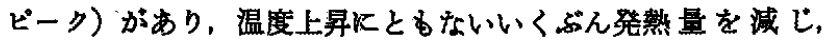
520 $610^{\circ} \mathrm{C}$ でさらに大きな発熱ピーク（第 2 発熱ピーク）をるつ 200 780 ${ }^{\circ} \mathrm{C}$ 領域での特徽のある形状をるつ発熱部を示す（表 3,

図 1 (I) の曲線（8）（15))。メタノールではこの形状は全体 としては変わらない。すなわら四熱ピークあるいは第 2 発熱ピー ク温度およびこの部分の形状は他とは变からない。しかし最初の 発熱ピークはこれより炭素鎖の長い場合とは異なり，いくよ゙ん高 温の $350^{\circ} \mathrm{C}$ あるいは $370^{\circ} \mathrm{C}$ に示される。この温度恃メタノール処 理シリカジルの示差熱分析の場合融と同じである。炭素鎖がこれ

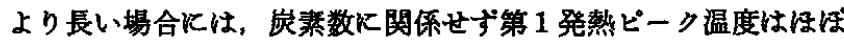
$220^{\circ} \mathrm{C}$ である（表 3, 図 1 (II) の曲線（8）（15)）から, メト キシ基の分解，然焼は他の付着基の場合より高温側で起こり，他 にくらべより安定であることを示していると考学られる。結合エ ネルギー17)の比較から C-O 結合の方が C-C 上りも強いと認め られるから、これは $>\mathrm{Si} \cdot-0-\mathrm{CH}_{3}$ 結合が $>\mathrm{Si} \cdot 0 \cdot \mathrm{CH}_{2}-\mathrm{CH}_{2} \cdot$ など の結合上りる強く，しかる分解と同時に燃烇が起こることを示唆 するものと考元られる。第 2 の発熱ピーク付近の形恃メタノール 処理の場合む含めて他の炭素数の大きな直鎖飽和アルコール処理 のすべての場合につき，SK 3 飞活性炭を混入した SK 3 (AC 3.38\%) の示美熱分析曲線（図 1（I）の曲線 ( 5 月) と発熱ピー ク温度も含めて同じ認めうる。したがってこの発熱部分は付着 基の熱分解怙よび不完全酸化により炭素の析出が起こり、これの 燃焼が支配的になる部分に相当するのであろら。このように考え るならば第 1 発熱領域は $200^{\circ} \mathrm{C}$ (メタノール処理のるのではより 高温の $270^{\circ} \mathrm{C}$ ) 付近で付着基の熱分解と酸化然焼とが試料の上部 から起こること，およびついで酸素の試料管内部への拡散の幄れ により生じる不完全然焼による炭素析出が起こることを示すと考 えられる。四 1 (II) の曲線（9)，(11）に示されるよらに 350 〜450 の温度額域でわずかではあるが吸熱部分が認められ，ま た他でる同温度領域で発熱量の減少が認められるのは，熱分解仡 よる炭化がこの温度領域で支配的起きていることを示してお り，上飞述べた見解を支持するるのと考えられる。これら析出炭 素が第 2 発熱ピーク付近で支配的になるとして，これらの発熱部 は合理的飞説明可能である。この部分での反応ははほ $600^{\circ} \mathrm{C}$ 以下 で起こるから，SK 3 (AC 3.38\%) の場合も含めて $\mathrm{C}_{x}+\mathrm{O}_{2} \longrightarrow$ $\mathrm{CO}_{2}+\mathrm{C}_{x-1}$ の反応 ${ }^{18}$ が支配的であろう。第 1 の発熱ピークの温度 $200 \sim 230^{\circ} \mathrm{C}$ は DSK 31 以下の炭素鎖のものでは表 1 第 10 列炕示 したように沸点またはそれ以上であるから，この温度以下での吸 熱部分性付着水の脱離敊よび末反応アルコールは残っているとし てもこの温度領域で脱離すると考えられる。これより高い温度で 発然反応が起きるのであるから，この分解酸化を示す付着基は単 なる吸着アルコールではなく，反応沉より結合していると考兄ら れる（とくに低沸点アルコールの場合にはこの傾向が顕著であ る)。これより炭素数の多い DDSK 21，MySK 31 では使用した

16) J.W. Hassler, “Activated Carbon”, Chem. Publ. Comp. Inc., (1963)；織田 孝, 江口良友訳, “活性炭效果的な利 用の基䃈と実際”，共立(1966) p. 158.

17) T. L. Cottrell, "The Strength of Chemical Bonds", Butterworths Sci. Publ. London (1958) p. 270.

18） J. W. Hassler，文献 16) の p. 159.
アルコールの沸点怢 $260^{\circ} \mathrm{C}$ あい恃それ以上である（表 2 第 10 列)。しかしこの場合る $220^{\circ} \mathrm{C}$ 付近で発熱ピークを示すの性付着 基であるアルコキシ基の分解がメチル基以上の炭素数をるつるの では一定であることを示すののである。したがって付着基は吸着 アルコールといった弱いあのではなく、シラノールとの反応作よ り結合しているるのであると教うるであろう。また酸来存在

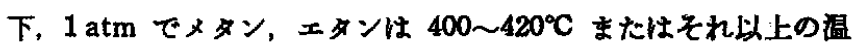
度で酸化反応性起こるのK対し，ブロパンは $375^{\circ} \mathrm{C}$, イソブタン は $350^{\circ} \mathrm{C}$ と炭素数增加比つれて反応は起こりやすいととが知られ ている(1)。これ炕反し，付着基の熱分解，酸化は炭素鎖の長さに

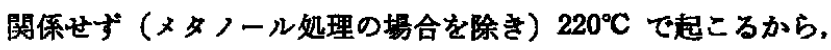
パラフィン系の酸化温度火くらべきわめて低い。このことる付着 基は反応炕より結合したものであることを示している。

4.1.3 分枝アルコール処理シリカゲル：側鎖をすつアルコー ルの場合には iso-, sec-ブタノール処理試料ともと曼熱, 発熱ピ ークの温度，発熱領域には 2 段階があること，および示差熱分析 曲線の形状性，前項の面鎖䭂和アルコール处理の場合とほぼ同し である（表 3，図 1 (III) の曲線（16)，(17))。しかし tert-ブ タノールあるいは tert-フミルフルコールは因 1 (III) の曲線 (18)，(19)，(20）飞示されるように，200足以下の吸熱，200〜 $800^{\circ} \mathrm{C}$ 間での挙動枋よび示差熱分析曲線の形状は iso-, sec-ブタ

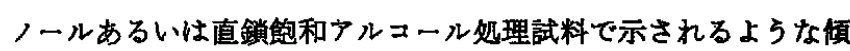
向は認められず，むしろ未処理シリカゲルの場合に一致する。し たがって tert-アルコールはシリカゲルとは反応しないと嘉めら れる。この傾向は後に述べる熱重量曲線の検討からる確かめられ た。これ(前報2)代示した tert-アルコールはシリカゲルと反応 しないとの結論を支持するるのである。しかしシリカゾルでは tert-ブタノールと反応するよらである゙から，これらの点はシラ ノールのエステル化反応の反応機構解明の点からも興味深い。

4.1.4 2 雨アルコールで処理されたシリカゲル： 2 価アルコ ール処理の場合は, 吸熱ピーク温度および㖟熱部の温度範囲は直 鎖飽和または tert-アルコール以外の分枝アルコールの場合之同 しであるが，鋭い第 1 発熱部のピークがこれより高温の 275〜305 ${ }^{\circ} \mathrm{C}$ 飞認められ，示差熱分析曲線の形での 2 価アルコール処理の場 合を特徽つ゚けている。第 2 発熱ピークは直鎖䭒和または分枝アル

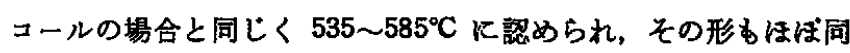
様である（表 3；因 1(N) の曲線(21)～(24)）。後者は前者下指 摘されたように付着基の熱分解と不完全然焼による析出炭素の燃 焼酸化による発熱部分と考えられる。第 1 発熱部の鋭いピーク括 よびその開始温度は他のアルコール処理の場合にくらべ, 50〜 $100^{\circ} \mathrm{C}$ 程度高温である。2 洒アルニール処理シリカゲルは他のア ルコール処理の場合が親油性であるのに反し，親水性であり， OH の一つがシラノールと反応し，未反応の $\mathrm{OH}$ が表面を扰拈ってい ることが認められだ24。したがってこの相違は新しい表面を形 成する付着基 $\mathrm{OH}$ によるものと考之られる。第 1 発熱領城が前项 に打けるのと同様付付着基の熱分解，酸化によるとした場合，分 解温度がより高温であるのは付着基は他のパラフィン系にくらべ 熱的任安定であることを示し，これは外側の炭素また汢中間の炭 素に OH が結合していることによると考えられる。このことは䓡 分解にさいしジオール，グリセロールと水酸基数が增すと熱的に 安定であること年からも妥当と考えられる。

4.1.5 芳香族了ルコールで処理したシリカゲル：この場合の 


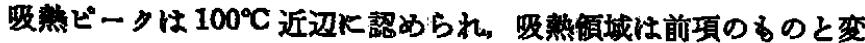
わらない。したがってこの部分では付着水の脱離が支配的であ

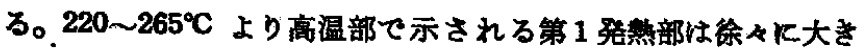
くなるが明らがぱークは認められず，大きな第 2 発熱部がつづ きピーク温度は $600^{\circ} \mathrm{C}$ 飞認められる（表 3，因 1 (V) の曲線 (25) (27))。このように示差熱分析曲線の形は他のアルコール 処理の㧹合と異なり特徽のある形を示す。結合エネルギー17の比

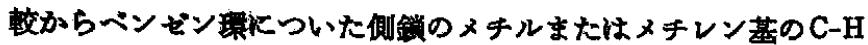
の方が桭内の C-H より酸化されやすいから，側鎖の脱水素，酸 化が少なくともその初期起こり，ついでフェニル基の C-H \& 含めて脱本素，酸化が起こると考光られる。前項化指摘したよう 飞第 1 発热部は付着基の熱分解，酸化によるるのとすれば，芳香 族アルコール処理の場合には他のアルコール处理の場 合にくら へ，资素含量が水案含量Kくらべ大きく，環の分解も起こり難い から，柴化が起こりやすいのであろら。したがって第 1 発熱部が あまり大きくないこの部分で付着基熱分解による炭素析出が起き ていると考えることは妥当であろう。このことも第 1 発热部が付 着基の熱分解，酸化を示しているとの前項の結論を支持するあの と考えられる。400 $600^{\circ} \mathrm{C}$ で第 2 発熱部仙前項と同様に析出

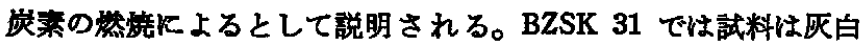
色であり，炭亲が湿入していることが確かめられているすこ。の 場合る第 1 発熱部はいちじるしくく，第 2 発熱ビークが $820^{\circ} \mathrm{C}$

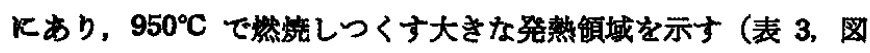
1 (V) の曲線（28）)。したがってこの揚合の反応恃

$$
\mathrm{C}_{x}+\mathrm{O}_{3} \longrightarrow 2 \mathrm{CO}+\mathrm{C}_{x-2}\left(800 \sim 900^{\circ} \mathrm{C}\right)
$$

飞相当するであら ${ }^{18)}$ 。 $800^{\circ} \mathrm{C}$ 飞加熱後の試料恃白色であり，赤 外吸収スペクトルです付着基は認められない。このことす SK 3 （AC 3.38\%）之同しく，第 2 発熱部は析出炭素の然锛によると 考えることの妥当性を示するのである。

4.1.6 不飽和直鎖了ルコールで処理 したシリカゲル：この場

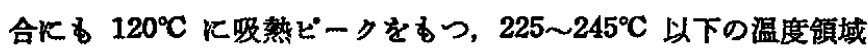
での吸愁部分恃, アリルアルコールの沸点が $97^{\circ} \mathrm{C}$ であるから， 付着水が残っているとすれば未反応アルコールの脱離に相当す る。第 1 発熱ピークは $285^{\circ} \mathrm{C}$ と $265^{\circ} \mathrm{C}$ とに認められ, 直鎖飽和了 ルニール処理の場合より高温である。第 2 発熱領域はあまりはっ きりとは区別されないが，それぞれ $400 ， 535^{\circ} \mathrm{C}$ 認められる （表 3, 四 1 (v) の曲線 (29)，(30))。第 1 発熱ピーク温度の高 いのは付着基に不飽和基を有するためと考之られ，これは岸化水 素の熱分解に䑙ける傾向20)とか結合エネルギーの比較に上る酸化 されやすさの傾问 ${ }^{14) 17}$ と一致する。末反応アルコールまな红吸着 フルコールがあるとしてる沸点付近で加熱すればすべて脱離する であろらから，このよらに発熱領域が沸点より高温側に認められ ることは付着基が単なる四着アルコールといったるのではなく、 反応により結合していることを示唆するるのであるう。

上飞述へたよらに示差熱分析曲線は付着基の種類により，それ ぞれ特徽のある形を示し，5種に大別される。付着水あるい性 っている場合には未反応アルコールの脱離による㖟熱ピークは未 処理シリカゲルも含めて，いずれの試料でも $120^{\circ} \mathrm{C}$ 近辺代認めら

19) C. D. Hurd, "The Pyrolysis of Carbon Compounds", Chem. Catalog. Comp. Inc., New York (1929) p. 176.

20） C. D. Hurd，文献 19）の p.71.
れる。

（1）未処理シリカゲルで示される $200 \sim 800^{\circ} \mathrm{C}$ 間の重量減少は 明らかであるが，熱の出入りはあまり䫒著でない型，(2）直鎖， 分枝アルコール処理試料で示される 200 220ㄷ での急激な発熱。 $300 \sim 400^{\circ} \mathrm{C}$ で発熱畫の減少㑯向（第 1 発熱领域），500 600 での大きな発熱がつづき， $600^{\circ} \mathrm{C}$ 付近で反応の終了する（第 2 発 熱領城)，箱型の示羔熱分析曲線，(3）2 価アルコール処理の場 合には同粎な型を示すが，第 1 発熱ピーク温度が $275 \sim 305^{\circ} \mathrm{C}$ と 高く,このピークが鋭く示される型，(4) 芳香族フルコール処 理の場合に示される第 1 発熱領域がなく，第 2 発熱領域の発達し た三角形型（5）直鎖不飽和アルコール処理の場合に示される 第 2 発㠇領域が顕著でなく，(4) とは逆な三角形型で，また第 1 発熱ビークが上り高温の $280^{\circ} \mathrm{C}$ 近辺にある型，の 5 種類である。 これから付着基の定生的な同定が可能と考えられる。この第 1 発 熱領域では付着基の熱分解とこれに付随して起こる然焼酸化が支 配的でありこえが付着基の種類に上り異なり特敏のある形を示 すと考光られる。この部分ではまた酸素の試料管内部への拡散が 幄いために，熱分解が支配的になるよらな吸熱傾向が大きく表わ れる場合すあるが，不完全燃焼による炭素析出がいずれの場合す 起こる。ついで析出炭素の燃酷酸化による発熱反応が支配的とな り，第 2 発熱領域を形成する。この領域が何度までつつくがは析 出炭素量にるよるが，ここで报った程度の付着基では $600^{\circ} \mathrm{C}$ 程度 で然焼しつくす。炎菜含量が大さく，また灰色化着色して明らか 飞析出炭莱が多いBZSK 31 では $950^{\circ} \mathrm{C}$ まで発熱がつつくこと からる，この推論の妥当性が諗められる。

\section{2 加熱過程で取り出した試料の检討}

1,4-ブタンジオールで処理した 1,4-BGSK 31 を昇温速度 $5^{\circ} \mathrm{C} /$ min でそれぞれ第 1 発熱ピークである $350^{\circ} \mathrm{C}$ ，分解燃焼の起き ている $445^{\circ} \mathrm{C}$ と第 2 発熱ピーク温度である $550^{\circ} \mathrm{C}$ および発熱反応 の終える $800^{\circ} \mathrm{C}$ にまで加熱したのち急命して取り出した陚料の着 色具合は，試料管の位置により異なり，350年では上部は淡黄褐 色，下部怕色で試料の大部分を示している。 $445^{\circ} \mathrm{C}$ では上部仕 溇茶禓色で試料の大部分を占め，わずかな量の下部は白色であ る。 $550^{\circ} \mathrm{C}$ では上部は白色試料が注将半分を占め，下部が濃茶褐 色であり， $800^{\circ} \mathrm{C}$ 加熱のものでは上下の別なく白色である。また 図2に示されるよらに示差熱分析曲線（1）（4）とそれぞれの 曲線は娜定された温度範囲で注注完全に一致する。また熱重量分 析曲線もその傾向は測定温度範囲内で一致する。このよ5に同一 温度加熱でる試料管の位置により陚料の色が異なるのであるか ら，その組成が試料管の位置で異なっていることを示し，それぞ れの温度で試料の熱分解あるい红酸化が試料管内部で均一に行な われているのではないことがわかる。したがって示差劄分析曲線 の変化を試料の分解あるいはこれにとすない生しる熱重量分析曲 線の変化とただちに定量的に関係つけることはできない。しかし 示差熱分析曲線 (1) （4)が測定温度範囲内で一致する傾向は再 現性のよいことを示するのであり，また熱重量分析曲線の傾向も 一致するのであるから，示差熱分析曲線の傾向はこの段階での支 配的な反応を表わしていると考兄るべきであるら。この上らに考 えるならば前項での検討の立場とも矛盾せず，検討結果も合理的 と考えられる。

これら陚料の赤外吸収スペクトルは図3に示されるよらに $350^{\circ} \mathrm{C}$ での上部淡黄褐色試料ではメチレン基の伸縮振動と㷌属さ 
れる $2930 \mathrm{~cm}^{-1}$ と $2850 \mathrm{~cm}^{-1}$ の忣収がわずかに 認められる（図 $3(2)) 。 こ れ と$ 同時に付着水によると認められる $3450 \mathrm{~cm}^{-1}$ の 幅広い吸収とこれの肩として認められる $3650 \mathrm{~cm}^{-1}$ の水秦結合し たシラノールの OH 伸紑振動と㛿属される吸収が原試料のそれら （図 3(1)）にくらへいちしるしく強く現われ，とくに原試料で はほとんど認められない $950 \mathrm{~cm}^{-1}$ の吸収が顕著に現われ，表 4 に示されるように $I_{\nu=850 \mathrm{~cm}^{-1}} / I_{\nu=800 \mathrm{~cm}^{-1}}$ は 1.39 で末処理シリカ ゲルのそれに近い値を示す。これ反し底部白色試料では図 3 （3）に示されるよらに，原試料のそれ（図 3 (1)) とまったく 同じである。したがって $350^{\circ} \mathrm{C}$ で上部試料は付着基の熱分解を起 こし，シラノール基が回復したのに対し，底部ではまだ分解反応 が進行していないことが認められた。 $445^{\circ} \mathrm{C}$ 加熱の濃茶褐色の上 部試料では付着基のコン䟽も認められず，ショノールの回復のみ が珰められる（四 $3(3)$ ，表 4)。白色の底部試料は原試料の赤 外吸収スペクトルと $950 \mathrm{~cm}^{-1}$ の曼取の傾向も含めて同じであり （図 3 (5)，表 4)，反応の起きていないことを示しているが， $350^{\circ} \mathrm{C}$ の場合にくらべその量はわずかである。550 $\mathrm{C}$ 加熱の上部 白色試料は図 3（4）と同じ赤外咋取スペクトルを示すが，これ は $I_{y=950 \mathrm{~cm}^{-1}} / I_{\nu=800 \mathrm{~cm}^{-1}}$ からむしろ図 $3(9)$ ，(10）の未処理シ リカゲル SK 3,n-ヘキサン処理シリカゲルSK 3 (n-hexane) のるのと同じと考光らるであろら（図 3（6），表 4)。したがっ て $445^{\circ} \mathrm{C}$ で析出した炭素す含めて酸化然焼が完結していると認め られる。下部泪茶褐色の武料では $2950,2870 \mathrm{~cm}^{-1}$ Kメチル基単 独の場合の $\mathrm{CH}$ 伸縮振動に㷌属される吸收 ${ }^{21}$ が認められ，1480 $\mathrm{cm}^{-1}$ のメチル基の変角振動とともにメタノール処理シリカゲル の赤外吸収スペクトル2) と類似であり，3650 $\mathrm{cm}^{-1}$ に首として示 される楅広い $3450 \mathrm{~cm}^{-1}$ の吸収が珰められ，表 4 に示されるよう K $I_{\nu=980} / J_{\nu=800}$ る末処理シリカゲルのそれとほぼ一致している。 このよらに熱分解過程の試料で分解された付着基のコン跡が認め られるのと同時に付着水とシラノールの回復のいちじるしいこと が諗められた。 $800^{\circ} \mathrm{C}$ 加鵁の試料では図 3 （8）のように付着水 あるい永素結合しているよらなシラノールなどす譛められず, また $950 \mathrm{~cm}^{-1}$ の吸取る認められない。したがって $800^{\circ} \mathrm{C}$ 加熱試 料では再水和の起こり難いことを示しており，これは従来報告さ れた傾向 ${ }^{22)}$ と同じである。

これらのことからつぎのよらなことが結論つけけられるである ら。（1）分解反応は試料管上部から底部へと進行する。（2）分 解にともない着色程度は白色＼cjkstart淡黄褐色 $\rightarrow$ 濃茶褐色 $\rightarrow$ 白色と変化 し，これに応じて反応は付着基の熱分解（酸化も含めて），炭素 析出, 析出炭素の燃焼の脽に先行する。（3）これらの反纫の進 行にともないシラノールの回復が瑟められ，950 $\mathrm{cm}^{-1}$ の吸収強

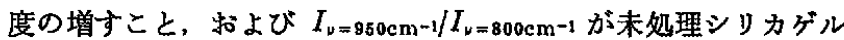
のそれに等しくなることが認められた。またこのシラノールの回 復が付着基のコン跡を残す試料掞よび濃茶褐色試料です認めら れ， $I_{\nu=950 \mathrm{~cm}^{-1}} / I_{\nu=800 \mathrm{~cm}^{-1}}$ の值ととるににとんど未処理陚料のそ れに等しいことは付着基の分解然焼が $\rightarrow \mathrm{SiO}-\mathrm{CH}_{2} \cdot \mathrm{CH}_{2}$ - の結合 の裂起を示唆するるのと考えられる。つぎに再水和し難い $800^{\circ} \mathrm{C}$ 加熱陚料では完全に消失する。前報2)では表面処理により观理程

21) A. Pozefski, N. D. Coggeshall, Anal. Chem., 23, 611 (1951).

22) M. L. Hair, "Infrared Spectroscopy in Surface Chemistry", Marcel Decker Inc., New York (1967) p. 85.
度に応じこの吸取强度が減少することから，ショノールの变角振 動と裙属した。付畕基索熱分解させて除くことKより $950 \mathrm{~cm}^{-1}$ の吸収が回膲する傾向は，前報”之は逆方向からの恰討飞相 当 し，これは前派》での $950 \mathrm{~cm}^{-1}$ 吸収の㷌属についての結䄖を支 持するすのである。（4）各処理温度での主反応は $350^{\circ} \mathrm{C}$ では付

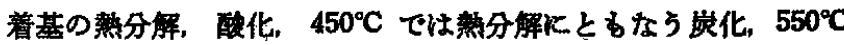

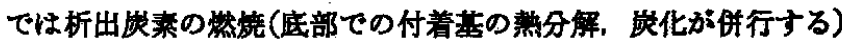
と瑟められる。この遏程で $550^{\circ} \mathrm{C}$ の底部泿茶楊色武料ではメチ ル基の存在が認められるから，この部位の試料では $>\mathrm{Si}-0$ $\left(\mathrm{CH}_{2}\right)_{2}-\mathrm{OH} \longrightarrow \mathrm{Si}-\mathrm{O}-\mathrm{CH}_{2}+2 \mathrm{H}_{2} \mathrm{O}+3 \mathrm{CO}_{2}$ (または $3 \mathrm{C}$ ) の反応 が起きており， >Si-0- $\mathrm{CH}_{8}$ が析出炭素とともに混在していると 考古られる。これが同じ着色度合を示す $445^{\circ} \mathrm{C}$ の上部灌茶祸色の あのでは彯められないことから，このよらな反応は酸絭供給の少 ない底部において起こり，中間的に $>\mathrm{Si}-\mathrm{O}-\mathrm{CH}_{8}$ が生成された

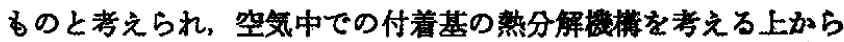
興味深い。

\section{3 熱重量分析曲線}

熱重量分析曲線の形は付着基の種類によりいくぶんかの遣い （たとえば減量曲線に変化をあたえる温度なと）はあるが，末処 理試料，表面処理試料によるるのとに大別される。末処理試料で は $T<200^{\circ} \mathrm{C}$ での急激な減少部分と $T>200^{\circ} \mathrm{C}$ での徐↔に減少 する部分とにわけられる。前者は示差熱分析曲線での吸熱部分K 相当し，後者はわずかな発熱または熱の出入りの琴められない部 分に相当する。表面処理試料で付付着基の種類にすよるが，同棣 に $T<200^{\circ} \mathrm{C}$ での急做な隇少部分之 $200^{\circ} \mathrm{C}<T<450^{\circ} \mathrm{C}$ での第 2 の急激な減少部分と $450^{\circ} \mathrm{C}<T<700^{\circ} \mathrm{C}$ の比較的徐々飞減少する 部分とにわけられる。前者は示盖熱分析曲線の吸熱部に相当し， 後 2 者は発熱部（それそれ第 1 発熱部、第 2 発熱部) に相当する。 とくに第 2 発熱部は減少量が小さいにもかかわらず発熱量は大を い。いずれの場合にる見られる $T<200^{\circ} \mathrm{C}$ の吸熱部は付着水また は末反応アルコールの脱離によると考えられる。

4.3.1 末処理シリカゲル：熱重睤分析曲線で $800^{\circ} \mathrm{C}$ なでの全 減少重量を水によるとして水素含量に换算するとおのおの表 2 第 7 列のよ5に，元素分析による水素含量（同表第 4 列）とほぼ等 しい。したがってこのよらにして求められる減量は元桲分析值と とるに十分妥当なるのと認められるであろう。

脱水減量の検討からシリカゲルは $150^{\circ} \mathrm{C}$ の加熱では $50 H / 100 \AA^{2}$ の水が牫り， $800^{\circ} \mathrm{C}$ 加熱でこれは $1 \mathrm{OH} / 100 \AA^{2}$ となることが知ら れている29)。したがって 150 800 $\mathrm{C}$ の加熱で 4 OH/100 $\AA^{2}$ の水 が脱離することになる。これから SK 2 の表面積を SK 2, SK 2 (n-hexane) の平均として $563 \mathrm{~m}^{2} / \mathrm{g}$, SK 3 の表面積を SK 3, SK 3 (n-hexane) の平均として $541 \mathrm{~m}^{2} / \mathrm{g}$ を用いて水の含異と して求めると，それぞれ 3.35，3.24\% となる。図 1 (I) の曲

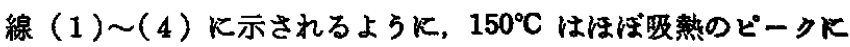
相当する。昇温速度を考虑するならば，同図の示差熱分析曲線が はほ原点にもどり，熱重量分析曲線でその勾配の変わる温度 $200^{\circ} \mathrm{C}$ が上に述べた脱水減量を検討するさいの $150^{\circ} \mathrm{C}$ に相当する であろら。したがって $200^{\circ} \mathrm{C}$ から $300^{\circ} \mathrm{C}$ 近辺までの減少重量を表 3 第 6 列の值を用い，SK 2,SK 2 ( $n$-hexane) の平均として求

23) M. L. Hair, 文献 16) の p. 24 ; V. Ya. Davydov, A. V. Kiselev, L. T. Zhuravlev, Trans. Faraday Soc., 60 , 2254 (1964). 
めðと $3.64 \%$ となり, SK 3,SK 3 (n-hexane) の平均として 求めると $4.04 \%$ となり、上記の脱水減量の検討による值とはほ 一致する。このことは SK 2,SK 3 の高盢㴭域での脱水は 4OH/

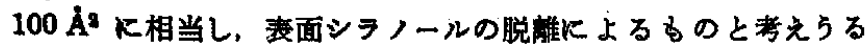
であろろ。

つぎに活性炭を混入したシリカゲル SK 3 (AC 3.38\%) の水 来含量を $200^{\circ} \mathrm{C}$ まての重量隇少と, SK 3 の $200^{\circ} \mathrm{C}$ 以上での淢 少重量とを加えたるのから求めると $1.61 \%$ (表 2 第 7 列) とな り、SK 3 の水莱含量 1.66\% と一致する。また SK 3 (AC 3.38 \%) の䓡重量曲線は $200 \sim 400^{\circ} \mathrm{C}$ でほぼ一定であり，400 以上

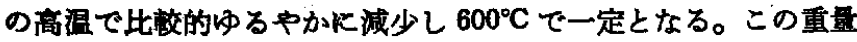
減少部分の発帮量は大きく，前項に指摘した第 2 発熱部分に相当 する。この温度領域での減少重量から SK 3 の $200^{\circ} \mathrm{C}$ 以上での 減少鬲五を差し引と $2.56 \%$ となり，当初の活性炭混入比率 3. 38\% にほぼ等しい。このことは未処理シリカゲルの脱办につ いての前に速べた機構の妥当性および前項での示差熱分析の結果 す含めて，400〜 $600^{\circ} \mathrm{C}$ での特徽のある示差熱分析曲線の形を示 す第 2 発熟部分は析出灰素の然焼によるとの結論の妥当であるこ とを示唆するるのである。

4.3.2 tert-フタタール, tert-アミルアルコール处理シリカゲ ル (tert-HBSK 2, tert-HBSK 3, tert-HASK 3) : 第三アル コールで処理したシリカゲルは未処理シリカゲルととの举動が 同じであることが前項での示盖熱分析曲線の検討括よび前報2) で の赤外吸収スペクトルの検討から認められ、これらは反応しない のであろらと結詥づけた。図 1（III）の曲線（18)，(19)，(20) に示されるように熱重量曲線もその形は $T<200^{\circ} \mathrm{C}$ での急滶な重 量減少部分之， $T>200^{\circ} \mathrm{C}$ での徐々に重量が減少する部分とが認 められるのみで，付着基の燃焼によると考えられる減量は認めら れず，むしろ末処理またはへキサン処理シリカゲルの場合とま。 たく一致する。 $T<200^{\circ} \mathrm{C}$ の減量から付着水は tert-HBSK 2, tert-HBSK 3, tert-HASK 3 でそれぞれ表3飞示されるように 9.65, 11.46, 2.9\%であり, SK 3, SK 3 (n-hexane) では 10.44, 11. 30\%である。 $T>200^{\circ} \mathrm{C}$ のシラノールの脱離によると考えら れる城量はそれぞれ 3.61，3.82，2.33\% であり，SK 3，SK 3 (n-hexane) では 4.31，3.77\% である。tert-HASK 3 はいずれ も低い値を示すが，他の 2 者はほぼ末処理シリカゲルのそれに一 致する。これから試料に含まれる水を水素含量として求めると表 2 第 7 列のように $1.47,1.52,0.71 \%$ となり, SK 3, SK 3 (n-hexane) の $1.64,1.66 \%$ と比較し, tert-HASK 3 は小さい が他の 2 者はほぼ一致する。このように tert-HASK 3 ではいず
れも未娌理シカゲルのそれにくらベ小さいが，熟重量分析曲線 の形からす，付着基が存在するとは考光られない。したがって第 三アルコールはシリカゲルとは反応しないことが熱重量分析曲線 の検討からす確かめられた。

4.3.3 衰面処理シリカゲル：tert-ブタノール, tert-アミルア ルコールを除いた他のアルコールで処理した試料では前に述べた 特徽のある形を熱重量分析曲線で示す。しかしこれらの減量部分 をただちに試料付着基の分解機構と対灾させて定量的に論ずるこ とができないことが前項に指摘された。熱重量分析曲線で $200<$ $T<450^{\circ} \mathrm{C}$ 領城のいらじるしい減少部分は付着基の熱分解と炭化 が主反応と認められ，発熱すあまり大きくない。これは熱分解と か炭化の吸熱が燃然による発熱を併存するからであろら。熱重量 分析曲線で示される $450<T<700^{\circ} \mathrm{C}$ での徐々に減少する領域は 示差熱分析曲線では第 2 発熱領域で発熱罢が大きく䫒著であるの は炭素の然焼を示していると考えた。 $T>200^{\circ} \mathrm{C}$ 以上の発熱領域 での重量减少甠付着基の分解，析出龙菜の燃焼によるとし，付着 基は使用した广ルコールのアルコキシ基であるとして求められた 炭素含量恃表 2 第 8 列に示された。 $T>200^{\circ} \mathrm{C}$ 発熱領域での SK 2 または SK 3 のシタノール含量を，この温度領域での表面処 理試料の減少重量から差し引き，付着基は使用したアルコールの アルキル基として求められた炭素含量は表 2 第 6 列に示した。付 着基がシラノールと反応して結合しているとすれば全シラノール が反応していないかぎり，実際の付着基炭案含墨は表 2 第 8 列に 示される値より小さく，表 2 第 6 列に示される倠より大きいであ ろら。表 2 第 3 列に示されるように元素分析による龙素含墨はこ れらの中間の妥当な值と認められる。このように表面処理試料で は付着基の熱分解, 酸化燃焼による減量は妥当であり，この減少 が直鎖および分枝飽和アルコール処理試料では $200^{\circ} \mathrm{C}$ 以上， 2 価アルコール処理のすのでは $270 \sim 305^{\circ} \mathrm{C}$ 以上, 不飽和アルコー ル処理のすのでは $250^{\circ} \mathrm{C}$ 以上であり，いずれる沸点以上である。 したがってこの発熱領域で分解を示す付着基は吸着アルコールの 上らなるのではなく，使用したアルコール中のアルキル基が反応 により結合していると認めらるであろら。これらの付着基の性質 の検討については等照射による ESR の検討とともに続行中 である。

本研究にさいし示差熱，熱重量分析の測定に便宜を御恵与下さ れ，御検討，御教示睗わった東北大学工学部田中弘文数授，なら びに赤外吸収スベクトルの測定に便宜を御恵与下され，御榆討， 御教示睗わった東北大学工学部会田高陽教授に深謝する。

（1972 年 4 月，第 26 回日本化学会春季年会（一部）発表）

\section{Studies on the Surface Groups of the Surface-Treated Silica Gels by Means of the Differential Thermal and Thermogravimetric Analysis ${ }^{\dagger}$}

Hiroshi Utsugi and Hideo Horikoshi

Department of Applied Science, Faculty of Engineering. Tohoku University; Sendai-shi, Japan

The surface groups of the silica gel treated by 22 kinds of alcohols (branched or linear saturated alcohol, diole, phenyl alcohol and unsaturated alcohol) were investigated through the DTA and TGA, in an air and in the temperature range from 20 to $800^{\circ} \mathrm{C}$. It was concluded as follows: (1) The shape of DTA curves was characterized by the alcohols used (2) Physically 
adsorbed water, or alcohol were evolved during the $200^{\circ} \mathrm{C}$ endotherm and the surface groups were thermally decomposed and were oxidized above the $200^{\circ} \mathrm{C}$ extensive exotherm (3) As to the native silica gels the physically adsorbed water was evolved during the $200^{\circ} \mathrm{C}$ endotherm and the silanol was evolved above $200^{\circ} \mathrm{C}(4)$ The surface groups began to decompose thermally and were oxidized at $250^{\circ} \mathrm{C}$ as to the silica gel treated by 'methanol, at $200 \sim 220^{\circ} \mathrm{C}$ as to the silica gels by branched or linear saturated alcohols except methanol, at $270 \sim 305^{\circ} \mathrm{C}$ as to the silica gels by dioles, at $265 \sim 285^{\circ} \mathrm{C}$ as to the silica gel by the unsaturated alcohol and at $220^{\circ} \mathrm{C}$ as to the silica gels by phenyl alcohols, respectively. The carbon was deposited in these exothermal region by the incomplete combustion (5) The combustion of the deposited carbon was a predominant reaction in the exothermal region from 400 to $600^{\circ} \mathrm{C}$ (6) The recovery of silanol through thermal decomposition of surface group and the occurrence of the inhomgeneous reaction at the various positions of testing tube were confirmed. They were verified by the respective samples after heating up to $350,445,550$ and $800^{\circ} \mathrm{C}$. The rehydration was not observed on the samples after heating above $800^{\circ} \mathrm{C}$. (7) Since the exothermal combustion of the surface group was observed at higher temperature than the normal boiling point, surface groups were not the adsorbed alcohol due to chemisorption, but chemically combined with silanal.

$\dagger$ Studies on the Surface Treatment of the Ultrafine Powders. XVII.

（日本化学会誌，1972，p. 2255～2259）

\section{グリセリドとコレステロールエステルの 混合単分子膜に対する水の透過性}

(1972 年 7 月 26 日受 理)

中 垣 正幸・舟畸 紀 昭*

\footnotetext{
グリセリドとコレステロールェステルの種々の組み合わせの混合単分子膜について，表面圧一平妁面積曲㟫および 水に対する蒸発比抵抗一表面圧曲線を求めた。

コレステロールフセテートの蒸発比抵抗はコレステロールのそれよりかなり高かったが,一方、コレステロールフ 七テート1 分子あたりの占有面積はコレステロールのそれにほぼ等しかった。和モノステフリンとコレステロール アセテートの混合単分子膜の比抵抗は，この混合単分子瞙の平均面糟が平坞面積の加成則からの計算值より小さかっ

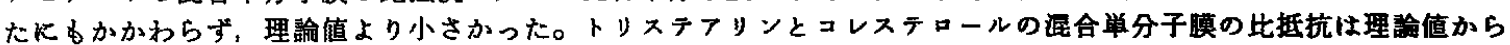
いくふんずれ，またこの混合単分子膜の平均面積は平均面碃の加成則からの計算值にほぼ等しかった。比抵抗に䦎す るこれらの結果は、これらの物賀の親水基に水和した水の構造に基ついて説明した。すなわちてセテート基は体水性 の水和をし、クリセロールエステル基忙親水性の水和をする。

$\alpha$-モノステフリンとコレステロールの混合単分子膜の比抵抗は $\alpha$-モノステフリン $1 \mathrm{~mol}$ とコレステロール $3 \mathrm{~mol}$ のモル比において極大であった。
}

\section{1 楮 需}

水面上の脂質単分子膜が水の蒸発速度を低下させることはよく 知られている1)。このような単分子膜の蒸発抑制作用については， 温度の影響1)2)，単分于膜中の炭化水素鎖の影蠁1), 膜の混合によ る影響1) および添加電解質の影製》に関する研究などがある。し かし親水基の影響に威する研究はまだ少ない。

* 京都大学薬学部, 京都市左京区吉田下阿達朾

1) G. T. Barnes, V.K. LaMer, "Retardation of Evaporation by Monolayers", ed. by. V.K. LaMer, Academic Press, New York, London (1962) p. 9.

2) R. J. Archer, V. K. LaMer, J. Phys. Chem., 59, 200(1955).

3）中垣正幸，舟㱦紀昭，日化，1972，1805.
てこで本埌ではグリセリドとコレステロールェステルの単分子 膜およびそれらの混合単分子膜に対する本の透過性を研究した。

\section{2 实僳}

2.1 譟 料

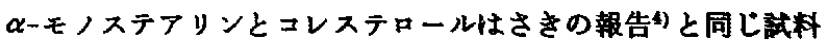
を用いた。トリステアリンは和光蚛薬の製品をトルェンから再郒 晶した。コレステロールアセテートは半井化学の製品をエタノー ルから再結晶した。コレステロールブロピオナートはAldrichの 製品をエタノールから再絬晶した。クロロホルムは試真特級を2 度蒸留した。

4）中垣正幸，舟崎紀昭，日化，1972，1576。 